Review

\title{
Systematic Review Of Diagnostic Utility Of Facet (Zygapophysial) Joint Injections In Chronic Spinal Pain: An Update
}

Nalini Sehgal, MD¹, Elmer E. Dunbar, MD², Rinoo V. Shah, MD³, and James Colson, MD ${ }^{4}$

From: ${ }^{1}$ University of Wisconsin School of Medicine and Public Health, Madison, WI; 'Pain Control Network, Louisville, KY; ${ }^{3}$ Guthrie Clinic, Sayre, PA; and 4West

Virginia University Hospitals, Morgantown, WV

Dr. Sehgal', Medical Director Interventional Pain Program, University of Wisconsin School of

Medicine and Public Health and Associate Professor Rehabilitation Medicine, Madison, WI. Dr. Dunbar is Medical Director, Pain Control Network, Louisville, KY. Dr. Shah ${ }^{3}$, Interventional Pain Management,

Department of Anesthesiology, Guthrie Clinic/Big Flats, Horseheads, NY; Dr. Colson 4 is Assistant Professor

Anesthesiology, Department of

Anesthesiology, Pain Medicine

Service, West Virginia University

Hospitals, Morgantown, WV. Address Correspondence: Nalini Sehgal, MD,

University of Wisconsin School of Medicine and Public Health, 600 Highland Avenue MC\#2424, Madison, WI 53595 E-mail: NSehgal@uwhealth.org Funding: None

Conflict of Interest: None.

Free Full manuscript www.painphysicianjournal.com
Background: A 2-year review of literature from October 2004 to December 2006 was completed to update current scientific evidence on diagnostic utility of facet joint injections. Diagnostic injections are employed to diagnose facet joint pain because available techniques cannot identify the pain generating structure in patients with chronic spinal pain. There is no physical examination technique, laboratory test, or imaging modality that can precisely identify the spinal structure causing pain, distinguish the culprit from a variety of potential targets, and predict response to a therapeutic intervention. Zygapophysial joint injections, commonly called facet injections (intra-articular joint injections and medial branch blocks) are local anesthetic injections of the facet joint or its nerve supply. These are diagnostic procedures used to determine if pain is arising from facet joints, distinguish painful from nonpainful joints and prognosticate response to therapeutic facet joint interventions. Diagnostic injections must meet the cardinal features of a diagnostic test i.e., accuracy, safety, and reproducibility. Accuracy is based on comparison with a "gold standard" to confirm presence or absence of a disease. There is, however, no available gold standard to measure presence or absence of pain. Hence, there is a degree of uncertainty concerning the accuracy of diagnostic facet joint injections.

Objectives: Evaluate and update available evidence (2004 to 2006) relating to clinical utility of facet joint injections (intraarticular and medial branch blocks) in diagnosing chronic spinal pain of facet joint origin

Study Design: Review of the literature for clinical studies on efficacy and utility of facet joint/nerve injections in diagnosing facet joint pain according to Agency for Healthcare Research and Quality (AHRQ) and Quality Assessment Studies of Diagnostic Accuracy (QUADAS) criteria. The level of evidence was classified as conclusive (Level I), strong (Level II), moderate (Level III), or limited (Level IV).

Methods: Computerized database search (2004 to 2006) of PUBMED, EMBASE, CINAHL, and Web of Knowledge was conducted to identify studies on facet joint pain and diagnostic interventions. Abstracts, reviews, book chapters, case reports, studies based on single blocks or blocks without radiologic control, and studies describing techniques were excluded. Prospective studies were given priority over retrospective studies.

Results: There is no change in the strength of evidence for facet joint diagnostic injections. There is strong evidence for controlled comparative local anesthetic facet joint injections or medial branch blocks in the diagnosis of neck and low back pain and moderate evidence in the diagnosis of pain arising from thoracic facet joints.

Conclusion: The evidence obtained from literature review suggests that controlled comparative local anesthetic blocks of facet joints (medial branch or dorsal ramus) are reproducible, reasonably accurate and safe. The sensitivity, specificity, false-positive rates, and predictive values of these diagnostic tests for neck and low back pain have been validated and reproduced in multiple studies.

Key words: Chronic spinal pain, neck pain, low back pain, cervical facet joint, thoracic facet joint, lumbar facet joint, zygapophyseal joint, medial branch block, intraarticular injection

Pain Physician 2007; 10: 213-228 
A systematic review of the diagnostic utility of facet or zygapophysial joint injections in chronic spinal pain was performed in 2004 (1). Spinal pain is a common cause of chronic pain and disability. Chronicity and disability from spinal pain are multifactorial, and associated with non-specific diagnosis and suboptimal outcomes. However, chronic refractory spinal pain continues to pose a peculiar diagnostic challenge because of multiple putative pain sources, overlapping clinical features, and non-specific radiologic findings. Diagnostic injection techniques are employed to isolate the source(s) of pain. Facet or zygapophysial joint pain is an example of spinal pain diagnosed by local anesthetic injections of the facet joint or its nerve supply.

Facet joints are a well-recognized cause of pain in subjects with persistent spinal pain (2). Spinal facet joints have been shown to be a source of pain in the neck and referred pain in the head and upper extremities (3-7); upper back and mid back and referred pain in the chest wall $(8,9)$; and the low back and referred pain in the lower extremity (10-15). Facet joints are well innervated by the medial branches of the dorsal rami (16-35). Neuroanatomic, neurophysiologic and biomechanical studies have demonstrated free and encapsulated nerve endings in facet joints, as well as nerves containing substance $P$ andcalcitonin gene-related peptide (35-50); facet joint capsules contain low-threshold mechanoreceptors, mechanically sensitive nociceptors, and silent nociceptors (35-53); and lumbar and cervical facet joint capsules can undergo high strains during spine loading (35,54-65). There are however, no specific clinical markers of facet joint pain.

Conventional clinical and radiologic techniques used to diagnose appendicular joint pain are unreliable in diagnosing zygapophyseal (facet) joint pain (1,66-113). Controlled local anesthetic blocks of the facet joint or its nerve supply are routinely employed to diagnose facet joint pain. The rationale for these blocks is that anesthetic blockade of a painful joint will abolish pain arising from that joint for the duration of the anesthetic effect, while anesthetic blockade of a nonpainful joint will not alter the pain report. The probability that the blocked joint is the actual source of pain is increased if repeating the block with an anesthetic agent that has a different duration of action reproduces the analgesic response (74). To ensure accuracy and validity these blocks must be controlled and verified for delivery of local anesthetic agent and placebo response. Fluoroscopic guidance and contrast enhancement enables precise delivery of local anesthetic agents to target structures. Dual or triple blocks are employed to eliminate placebo responses. Single facet joint injections are not recommended, as they do not control for a falsepositive response $(74-76,78-80,82,114-132)$. The placebo controlled technique is considered the gold standard, but has limited clinical utility due to ethical and cost implications. A controlled comparative block with short and long acting local anesthetics is an acceptable alternative strategy $(1,74-76,114,115,133,134)$.

Controlled comparative blocks have been criticized and the accuracy and validity of these precision diagnostic techniques have been questioned $(122,123,130,135-$ 138). Although these tests control and verify for location of local anesthetic delivery, they are faulted for assuming that the report and documentation of the magnitude and quality of pain relief are accurate. Because these tests employ subjective criteria i.e., rely on a patient's report of presence or absence of pain following a block, and ability to isolate different painful areas, or differentiate between significant and insignificant pain relief (when pain relief is incomplete) they promote doubt about the accuracy of these procedures.

Hildebrandt (123), in an extensive review on the relevance of diagnostic zygapophysial joint blocks, questioned the anatomic and physiologic premises for neural blockade. Nachemson and Vingård (138) opined that except for imaging studies, all other studies failed to demonstrate clinical utility in assessment of neck or back pain. Ramsey et al (139) believed facet blocks, discography, and diagnostic nerve root infiltration lacked scientific rigor. North et al (121) reported a limited role for uncontrolled local anesthetic blocks in the diagnostic evaluation of sciatica and referred pain syndromes in general. They concluded that negative blocks may have some predictive value, but isolated, positive blocks are non-specific. Leonardi et al (135) described that one rationale for spinal injections is to provide or eliminate pain presumably caused by the target spinal structure; this ostensibly allows a physician to make a better assessment of whether a particular morphologic alteration does or does not cause symptoms. They also described that another rationale is to use spinal injections to support conservative treatment in patients who have pain from nerve root compromise, spinal stenosis, or facet joint osteoarthritis. They concluded that despite the widespread use of these spinal injections, their application is based widely on anecdotal experience and evidence that is not evidence-based.

Waggershauser et al (136) described that in a maximum of $7 \%$ of cases, the pain is radicular $(4 \%$ 
due to intervertebral discs and $3 \%$ caused by stenosis), in $7 \%$ to $15 \%$ of cases, the pain's origin is located in the region of the vertebral joints and in up to $15 \%$ in the region of the sacroiliac joint. They described that although the overwhelming majority of pain has no clear structural cause, infiltrations of medications and nerve blockades are frequently employed. They also emphasized that the efficacy of these procedures has not been verified in controlled studies with the exception of epidural injection of corticosteroids for radicular pain.

Resnick et al (137) reviewed accuracy and effectiveness of interventional techniques. There is evidence that suggests that facet joint injections can be used to predict outcome after radiofrequency ablation of a facet joint. However, they emphasized that the predictive ability of facet joint injections does not appear to apply to lumbar fusion surgery. However, they commented that no evidence exists to support the effectiveness of facet injections in the treatment of patients with chronic low back pain.

Proponents of diagnostic blocks suggest that precise fluoroscopically guided needle techniques can selectively and accurately target deep and inaccessible spinal structures such as disc, facet joints or spinal nerves and can individually assess each of these structures' contribution to a subject's pain $(1,74-76,85,124)$. These structures can then be selectively blocked with small volumes of appropriately placed local anesthetics, and the delivery of these agents can be controlled and verified to ensure that only the target structure is anesthetized (85). In this manner it can be determined physiologically if the structure is indeed painful or not.

Accuracy of a diagnostic test is described in terms of specificity and sensitivity of the test. Specificity is a relative measure of the prevalence of false-positives, whereas sensitivity is the relative prevalence of falsenegative results. None of the tests available in clinical medicine have $100 \%$ sensitivity and specificity; there is invariably a degree of uncertainty regarding the accuracy of each and every diagnostic test as applied to an individual clinical case.

Saal (124) considers precision diagnostic spinal injections to be physical examination tests that, unlike most laboratory tests used in clinical medicine, lack an absolute gold standard in the form of a tissue diagnosis for comparison. Although these tests depend on abolition or reproduction of the patient's pain symptoms to make a diagnosis, they should not be regarded as useless or invalid.
Bogduk and McGuirk $(72,85-88,140,141)$ described the accuracy and value of precision diagnostic blocks, proposed an algorithmic approach to diagnosis of chronic spinal pain and defined the role of precision diagnostic blocks in the diagnosis and treatment of chronic low back and neck pain. Boswell et al (66), in an evidence-based evaluation of diagnostic facet joint blocks provided strong affirmation of the validity, specificity, and sensitivity of facet joint nerve blocks in the diagnosis of spinal pain of facet joint origin. Boswell et al (75) and Sehgal et al (1), in a systematic review, reported the accuracy of precision, controlled diagnostic blocks in the diagnosis of chronic spinal pain of facet joint origin.

By applying stringent criteria as recommended by International Association for the Study of Pain (IASP) (142) and using controlled diagnostic blocks, construct validity of facet joint blocks is maintained $(1,74-$ $84,114-120,125-129,131-134)$. Face validity of facet joint blocks has been demonstrated in various studies $(21,23,24)$.This systematic review was undertaken to update the literature and determine the accuracy of facet joint blocks in the diagnosis of chronic spinal pain.

\section{Methods}

\section{Search Strategy}

A computerized database search (October 2004 to December 2006) of PUBMED, EMBASE, CINAHL, and Web of Knowledge was performed. The search included manual searches of bibliographies of systematic and narrative reviews and cross references to the reviews. Keywords used in the search were facet joint/ zygapophyseal joints as causes of neck/back pain; facet joint/diagnostic injections; diagnostic joint and nerve injections.

\section{Inclusion Criteria}

Prospective and retrospective studies on diagnostic facet joint procedures in patients with spinal pain of $>3$ months duration were included for review. Studies were included if the injections were fluoroscopically/ image guided and controlled for false-positive responses i.e., used comparative control or placebo control blocks. Controlled, double-blind studies were given priority over cohort and observational studies in grading of the evidence. The criterion standard for diagnosis of zygapophysial facet joint pain was at least $>50 \%$ pain relief for the duration of local anesthetic effect. 


\section{Exclusion criteria}

Papers excluded from review were anatomical/cadaver studies, studies describing injection techniques, ultrasound guided injections, case reports, chapters, reviews, guidelines, letters, and expert opinions. Studies that failed to exclude a false-positive response, or consisted of injections that were not image guided were not considered for this review. Also excluded were papers on therapeutic facet joint procedures e.g., radiofrequency neurotomy, intraarticular steroid injections, and therapeutic medial branch blocks.

\section{Method of Review}

Abstracts obtained from computerized database searches were initially screened for exclusion criteria. Two physician reviewers evaluated and graded articles meeting inclusion criteria for methodologic quality and grading of evidence. AHRQ (Agency for Healthcare Research and Quality) criteria and QUADAS criteria as illustrated in Tables 1 and 2 were employed and all studies fulfilling $>3 / 5$ AHRQ criteria and/or > 7/14 QUADAS criteria formed the subject of this review $(143,144)$

\section{Results}

Database searches yielded 44 articles on facet/ zygapophysial joints, including 2 articles in press (145-156). Thirty-seven papers were excluded for the reasons shown in Table 3. Two of the 7 studies on controlled comparative local anesthetic blocks described prevalence rates of facet pain and false-positive rates. These studies were similar in methodology, outcomes assessment, and statistical analyses to earlier studies by the same authors. Both studies from the current search were added to the previously established database of 37 studies (1966 to 2004). Salient characteristics of these studies have been described in detail in a previous systematic review by Sehgal et al (1).

\section{Diagnostic Accuracy \& Prevalence Studies}

There were 2 retrospective studies of which 1 was excluded (145); a second study on prevalence of facet joint pain and false-positive rate of diagnostic facet blocks (131) met criteria and was included in the review. In the retrospective survey of 500 patients with spinal pain, controlled, comparative local anesthetic medial branch blocks revealed that the prevalence of facet joint pain for cervical spine was 39\%, thoracic spine was $34 \%$ and lumbar spine was $27 \%$. Single lidocaine medial branch blocks had a false-positive rate of $45 \%$ in the cervical spine, $42 \%$ in the thoracic spine and, and $45 \%$ in the lumbar spine. These figures are lower than the previously reported prevalence rates and false-positive rates (118) and most likely are a function of stringent diagnostic criterion i.e., use of $80 \%$ or greater pain reduction criterion for a positive response to medial branch blocks.

Table 1. Domains and elements for diagnostic studies developed by the Agency for Healthcare Research and Quality (AHRQ)

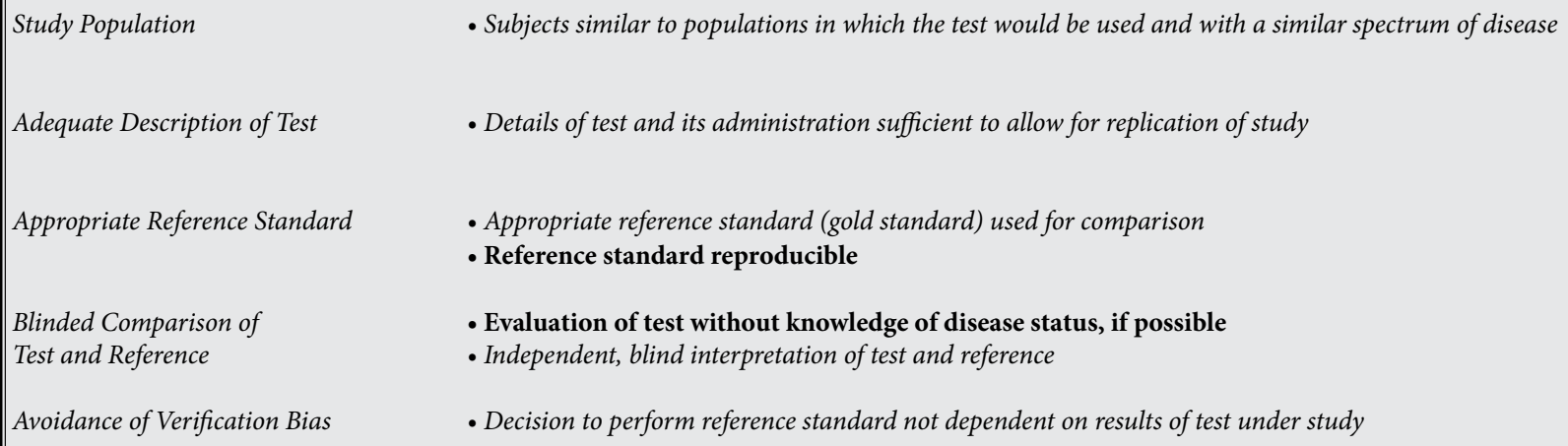

\footnotetext{
\# Key domains are in italics

*Elements appearing in italics are those with an empirical basis. Elements appearing in bold are those considered essential to give a system a Yes rating for the domain.
}

Adapted from ref 143 
Table 2. Items utilized for assessment of quality of individual articles of diagnostic studies by QUADAS tool

\begin{tabular}{|c|c|c|c|}
\hline Item & Yes & No & Unclear \\
\hline 1. Was the spectrum of patients representative of the patients who will receive the test in practice? & ( ) & () & ( ) \\
\hline 2. Were selection criteria clearly described? & () & $($ ) & $($ ) \\
\hline 3. Is the reference standard likely to correctly classify the target condition? & ( ) & $($ ) & ( ) \\
\hline $\begin{array}{l}\text { 4. Is the time period between reference standard and index test short enough to be reasonably sure that the target } \\
\text { condition did not change between the two tests? }\end{array}$ & ( ) & () & ( ) \\
\hline $\begin{array}{l}\text { 5. Did the whole sample or a random selection of the sample, receive verification using a reference standard of } \\
\text { diagnosis? }\end{array}$ & ( ) & () & ( ) \\
\hline 6. Did patients receive the same reference standard regardless of the index test result? & () & () & () \\
\hline $\begin{array}{l}\text { 7. Was the reference standard independent of the index test (i.e. the index test did not form past of the reference } \\
\text { standard)? }\end{array}$ & ( ) & $($ ) & ( ) \\
\hline 8. Was the execution of the index test described in sufficient detail to permit replication of the test? & () & () & ( ) \\
\hline 9. Was the execution of the reference standard described in sufficient detail to permit its replication? & ( ) & $($ ) & ( ) \\
\hline 10. Were the index test results interpreted without knowledge of the results of the reference standard? & ( ) & $($ ) & $($ ) \\
\hline 11. Were the reference standard results interpreted without knowledge of the results of the index test? & () & () & ( ) \\
\hline $\begin{array}{l}\text { 12. Were the same clinical data available when test results were interpreted as would be available when the test } \\
\text { is used in practice? }\end{array}$ & ( ) & $($ ) & $($ ) \\
\hline 13. Were uninterpretable/intermediate test results reported? & () & $($ ) & ( ) \\
\hline 14. Were withdrawals from the study explained? & () & $($ ) & ( ) \\
\hline
\end{tabular}

Adapted from ref 144

Table 3. Articles excluded from review

\begin{tabular}{|l|c|}
\hline \hline Topic of paper & Number \\
\hline No original data (essay, review, letter) & 17 \\
Designs flaw or diagnosed on single injection (one in foreign language) & 2 \\
Survey need for conscious sedation & 1 \\
Technique only (six studies on ultrasound guided technique) & 8 \\
Complication only & 7 \\
Not English language & 2 \\
\hline \hline
\end{tabular}


Manchikanti et al (132) reported a $16 \%$ prevalence of lumbar facet joint pain in a prospective study of 117 post surgical patients. The false-positive rate was $49 \%$.

A retrospective study by Cohen et al (146) evaluated lumbar facet joint pain in soldiers and retirees and sought to determine factors associated with falsepositive medial branch blocks. The authors review of medical records of 78 patients undergoing diagnostic medial branch blocks and provocative discography. There were $52(67 \%)$ patients with a negative response (negative blocks) and 26 (33\%) with $50 \%$ or greater pain relief after single medial branch block who did not respond to subsequent facet RF neurotomy (falsepositive). Data on subjects without pain relief after medial branch blocks (negative blocks) and after lumbar radiofrequency neurotomy (false-positive) were analyzed; of $75 \%$ of subjects with negative blocks and $3 \%$ with false-positive blocks had positive discography. The authors concluded that failure to control for a false-positive response prior to radiofrequency neurotomy resulted in high failure rate. This study exemplifies the importance of excluding false-positives prior to definitive treatments for facet joint pain.

\section{Clinical and Radiological Predictors of Facet Pain}

Laslett et al (111) analyzed data from a prospective blinded study of 120 chronic LBP subjects receiving zygapophysial joint blocks $(n=151)$, to identify clinical variables predictive of a positive response to screening facet joint blocks. Pain reduction after screening zygapophysial joint blocks was categorized in 5\% increments and diagnostic accuracy values calculated for clinical variables and variable clusters in relation to different pain reduction standards. Seven clinical findings in 4 different combinations (CPR or clinical prediction rules) were determined to be superior at predicting the outcome of a single zygapophysial joint block at $95 \%$ pain reduction standard. A combination of clinical variables was found to be highly sensitive in predicting a negative response to the screening zygapophysial joint blocks. In another prospective blind study by the authors $(113,147)$, they sought to determine diagnostic agreement between clinical diagnoses and diagnoses based on available reference standards for known causes of LBP, (e.g., disc or facet, SIJ, hip joint injections, advanced imaging studies, or any combinations of these). The study evaluated 216 LBP subjects and a proportional chance statistic of $33 \%$ and kappa statistic of 0.31 were calculated.
Pneumaticos et al (112) prospectively evaluated use of bone scintigraphy with SPECT for identifying patients with low back pain requiring facet joint injections. A total 47 LBP patients were randomized to receive SPECT scan (A) and no scan (B). Subjects with a positive SPECT scan (A1) received facet joint injections at the level reported as abnormal on the SPECT scan. Subjects with negative scan (A2) and those randomized to no scan group (B) underwent facet joint injections at predetermined levels. Thirteen of 15 patients in Gp.A1, 2/16 in Gp.A2, and 5/16 in Gp.B reported >1 SD pain score improvement at one month. Based on the reduction in the number of facets injected from 60 to 27 in Gp A1, Medicare cost was calculated to decrease from $\$ 2191$ per patient to $\$ 1865$ with use of SPECT.

Houseni et al (148) demonstrated the potential of fluorodeoxyglucose (FDG) positron emission tomography (PET) in the diagnosis of facet joint arthropathy.

Kim and Wang (149) performed MRI scans and SPECT (single photon emission computed tomography) scans, to study 230 facet joint in patients with facet mediated axial back pain. The authors reported that facet hypertrophy did not predict anormal (positive) SPECT scan, but synovial anormalities correlated with findings on SPECT scans.

\section{Confounding Factors}

Conscious sedation during diagnostic injections can modify the pain experience and result in lower pain ratings. Studies by Manchikanti et al (150-153) have demonstrated that conscious sedation may introduce a slight false-positive response due to the analgesic, sedative, and anxiolytic properties of fentanyl and midazolam. This effect can be minimized by employing strict criteria for identifying positive analgesic response as shown previously by the author.

In a recent study, Manchikanti et al (152) examined the confounding influences of conscious sedation on diagnostic injections in subjects with both cervical and lumbar facet pain. Sixty patients with established diagnoses of cervical and lumbar facet pain and presenting for therapeutic medial branch blocks, received in a randomized double blind placebo controlled manner, intravenous saline, midazolam or fentanyl until relaxed/sedated or delivery of maximum predetermined dose. Subjects were evaluated for percentage of pain relief and ability to perform previously painful movements. $5 \%$ of subjects in the placebo group, and up to $10 \%$ subjects in the active drug group reported 
$>80 \%$ pain relief and were able to perform movements that were painful prior to administration of IV agents. Application of $>80 \%$ pain reduction criterion standard instead of $>50 \%$ pain reduction decreased the false-positive response from $15 \%$ to $10 \%$. Earlier studies demonstrated placebo and nocebo effects of sedation $(150,151)$ and lack of confounding influence of psychological factors (154).

\section{Safety and Complications}

There was one case report of transient paraplegia after a cervical facet joint injection performed without imaging guidance (155). A vasovagal episode and short duration procedure-related discomfort was reported in the past (156). Multiple other complications were reported with infection and bleeding (157-162).

\section{Validity}

Medial branch blocks have been shown to maintain face validity. Local anesthetic injected accurately onto the correct target points selectively infiltrates the target nerve, and does not anesthetize adjacent structures that might be an alternative source of pain to the zygapophysial joint $(21,23)$. In addition, medial branch blocks have been shown to protect normal volunteers from pain provoked experimentally from the anesthetized joint (24).

Medial branch blocks have been shown to demonstrate construct validity. However, to have construct validity, medial branch blocks must be controlled. Single diagnostic blocks carry a false-positive rate of $27 \%-63 \%$ in cervical spine, $42 \%-58 \%$ in the thoracic spine, and $17 \%-47 \%$ in lumbar spine $(1,74-80,82,116$ $120,125-129,131,132)$. Patients may report relief of pain after a diagnostic block for reasons other than the pharmacologic action of drug administered (114). Thus, it is essential to know the true positive response in every individual case. The validity of controlled comparative local anesthetic blocks for facet joint diagnostic blocks was confirmed with placebo-controlled diagnostic blocks $(114,115)$.

\section{Criterion Standard}

No tissue diagnosis (biopsy or autopsy) techniques are available to diagnose facet joint pain and confirm specificity and sensitivity of medial branch blocks. However, pain relief and stability of the diagnosis with long-term follow up are employed as the criterion standards and are accepted across different medical disciplines $(1,124,163)$.
Several studies evaluating the effectiveness of various therapeutic modalities have shown the existence of facet joint pain. Furthermore, Manchikanti et al (163) established the diagnostic validity of lumbar medial branch blocks on long-term follow-up at 2 years after the initial diagnosis of lumbar facet joint pain in patients with chronic low back pain.

\section{Prevalence}

In the 2004 systematic review by Sehgal et al (1), 19 papers provided prevalence estimates for lumbar, thoracic, and cervical facet joint pain (77-84,116$120,126-128,131,132,156)$. Data on cervical and lumbar facet joint pain have been replicated in multiple studies conducted in academic and private practice settings in Australia and the United States. Tables 4 to 6 (updated in 2006) highlight study characteristics separately for cervical, thoracic, and lumbar facet pain. A number of studies have also evaluated treatment outcomes in subjects undergoing therapeutic procedures after comparative controlled diagnostic blocks and uncontrolled diagnostic blocks (164-174).

Based on the results of these studies, facet joints have been implicated as a source of chronic spinal pain in $15 \%$ to $45 \%$ of a heterogeneous group of patients with chronic low back pain, $34 \%$ to $48 \%$ of the patients with thoracic pain, and $36 \%$ to $67 \%$ of the patients with chronic neck pain.

\section{False-Positive Rates}

After careful review, 16 relevant studies evaluating false-positive rates were included for evidence synthesis. All of these studies reported false-positive rates either independently or in conjunction with other parameters. The details are shown in Tables 46. These studies implicated single blocks as a source of false-positive results in $27 \%$ to $63 \%$ of patients in the cervical spine, $42 \%$ to $58 \%$ of the patients in the thoracic spine, and $17 \%$ to $47 \%$ in the lumbar spine.

\section{Discussion}

The current review is an update of the comprehensive literature search and analysis conducted for a systematic review in 2004 (1). Diagnostic studies were evaluated in accordance with AHRQ (143) and QUADAS (144) criteria as shown in Tables 1 and 2. At least 3 AHRQ and 7 QUADAS criteria were met by each study included in this review.

None of the studies reviewed changed the diagnostic accuracy of facet or zygapophysial joint blocks, 
Table 4. Data of prevalence with controlled diagnostic blocks and false-positive rates in cervical region

\begin{tabular}{|c|c|c|c|c|c|c|}
\hline \multirow{2}{*}{ Study } & \multicolumn{2}{|c|}{ Quality Scoring } & \multirow{2}{*}{$\begin{array}{c}\# \text { of } \\
\text { Subjects }\end{array}$} & \multirow{2}{*}{ Type } & \multirow{2}{*}{ Prevalence } & \multirow{2}{*}{ False-Positive Rate } \\
\hline & AHRQ & QUADAS & & & & \\
\hline Barnsley et al (125) 1993 & $4 / 5$ & $13 / 14$ & 55 & RCT & NA & $\begin{array}{l}27 \%(95 \% \text { CI 15\%- } \\
38 \%)\end{array}$ \\
\hline Barnsley et al (83) 1995 & $4 / 5$ & $13 / 14$ & 50 & $\mathrm{P}, \mathrm{DB}$ & $54 \%$ (95\% CI 40\%-68\%) & NA \\
\hline Lord et al (84) 1996 & $4 / 5$ & $13 / 14$ & 68 & $\begin{array}{l}\mathrm{RCT} \\
\mathrm{DB}, \\
\mathrm{PC}\end{array}$ & $60 \%$ (95\% CI 46\%-73\%) & NA \\
\hline Manchikanti et al (120) 2002 & $3 / 5$ & $10 / 14$ & 106 & $\mathrm{P}$ & $60 \%$ (95\% CI 50\%-70\%) & $\begin{array}{l}40 \%(95 \% \text { CI 25\%- } \\
56 \%)\end{array}$ \\
\hline Manchikanti et al (117) 2002 & $3 / 5$ & $10 / 14$ & 120 & $\mathrm{P}$ & $67 \%$ (95\% CI 58\%-75\%) & $\begin{array}{l}\text { 63\% (95\% CI } 48 \% \text { - } \\
78 \%)\end{array}$ \\
\hline Manchikanti et al (118) 2004 & $3 / 5$ & $11 / 14$ & $\begin{array}{c}255 \text { of } 500 \\
\text { patients }\end{array}$ & $\mathrm{P}$ & $55 \%$ (95\% CI 49\%-61\%) & $\begin{array}{l}63 \%(95 \% \text { CI } 54 \%- \\
72 \%)\end{array}$ \\
\hline Manchukonda et al (131) 2007 & $3 / 5$ & $9 / 14$ & $\begin{array}{l}251 \text { of } 500 \\
\text { patients }\end{array}$ & $\mathrm{R}$ & $39 \%$ (95\% CI, 32\%-45\%) & $\begin{array}{l}45 \%(95 \% \text { CI, } 37 \% \\
-52 \%)\end{array}$ \\
\hline Speldewinde et al (156) 2001 & $3 / 5$ & $7 / 14$ & 97 & $\mathrm{R}$ & $36 \%$ (95\% CI, 27\%-45\%) & NA \\
\hline
\end{tabular}

$R C T=$ randomized, controlled trial; $P=$ prospective; $S B=$ single blind; $R=$ retrospective; $P C=$ placebo controlled; $D B=$ double blind; $N A=$ not available

Table 5. Data of prevalence with controlled diagnostic blocks and false-positive rates in thoracic region

\begin{tabular}{|c|c|c|c|c|c|c|}
\hline \multirow{2}{*}{ Study } & \multicolumn{2}{|c|}{ Quality Scoring } & \multirow{2}{*}{$\begin{array}{c}\text { \# of } \\
\text { Subjects }\end{array}$} & \multirow{2}{*}{ Type } & \multirow{2}{*}{ Prevalence } & \multirow{2}{*}{ False-Positive Rate } \\
\hline & AHRQ & QUADAS & & & & \\
\hline Manchikanti et al (118) 2004 & $3 / 5$ & $11 / 14$ & $\begin{array}{c}72 \text { of } 500 \\
\text { patients }\end{array}$ & $\mathrm{P}$ & $42 \%$ (95\% CI 30\%-53\%) & $\begin{array}{l}55 \%(95 \% \text { CI 39\%- } \\
78 \%)\end{array}$ \\
\hline Manchikanti et al (119) 2002 & $3 / 5$ & $10 / 14$ & 46 & $\mathrm{P}$ & $48 \%$ (95\% CI 34\%-62\%) & $\begin{array}{l}58 \% \text { (95\% CI 38\%- } \\
78 \%)\end{array}$ \\
\hline Manchukonda et al (131) 2007 & $3 / 5$ & $9 / 14$ & $\begin{array}{c}65 \text { of } 500 \\
\text { patients }\end{array}$ & $\mathrm{R}$ & $34 \%$ (95\% CI, 22\%-47\%) & $\begin{array}{l}42 \% \text { (95\% CI, 26\%- } \\
59 \%)\end{array}$ \\
\hline
\end{tabular}

$P=$ prospective $R=$ retrospective

which as reported previously is strong for cervical and lumbar facet joints and moderate for thoracic facet joints.

A recent study revealed that when more stringent criteria ( $>80 \%$ pain reduction) were used, the prevalence of facet joint pain was $39 \%$ in the cervical spine, $34 \%$ in the thoracic spine and $27 \%$ in the lumbar spine (131). Uncontrolled or single medial branch blocks had a false-positive rate of $45 \%$ in the cervical and lumbar spine, and $42 \%$ in the thoracic spine. These figures are within the previously reported range of $15 \%$ to $45 \%$ for lumbar spine but lower than the $42 \%$ to $48 \%$ prevalence rates for thoracic facet pain and $54 \%$ to $67 \%$ prevalence rates for cervical spine pain. Prevalence of lumbar facet pain in failed back surgery patients was $16 \%$ (132). 
A Systematic Review of Diagnostic Utility of Facet (Zygopophysial) Joint Injections

Table 6. Data of prevalence with controlled diagnostic blocks and false-positive rates in lumbar region

\begin{tabular}{|c|c|c|c|c|c|c|}
\hline \multirow{2}{*}{ Study } & \multicolumn{2}{|c|}{ Quality Scoring } & \multirow{2}{*}{ \# of Subjects } & \multirow{2}{*}{ Type } & \multirow{2}{*}{ Prevalence } & \multirow[t]{2}{*}{ False-Positive Rate } \\
\hline & AHRQ & QUADAS & & & & \\
\hline $\begin{array}{l}\text { Schwarzer et al (77) } \\
1994\end{array}$ & $4 / 5$ & $12 / 14$ & 176 & $\mathrm{P}$ & $\begin{array}{l}15 \%(95 \% \text { CI } 10 \%- \\
20 \%)\end{array}$ & $\mathrm{NA}$ \\
\hline $\begin{array}{l}\text { Schwarzer et al (129) } \\
1994\end{array}$ & $4 / 5$ & $12 / 14$ & 176 & $\begin{array}{l}\text { Subjects } \\
\text { from } \\
\text { previous } \\
\text { study }\end{array}$ & $15 \%$ & $\begin{array}{l}38 \% \text { (95\% CI 30\%- } \\
46 \%)\end{array}$ \\
\hline $\begin{array}{l}\text { Schwarzer et al (81) } \\
1995\end{array}$ & $1 / 4$ & $12 / 14$ & 63 & P, SB & $\begin{array}{l}40 \%(95 \% \text { CI 27\%- } \\
53 \%)\end{array}$ & NA \\
\hline $\begin{array}{l}\text { Manchikanti et al } \\
\text { (78) } 1999\end{array}$ & $3 / 5$ & $8 / 14$ & 120 & $\mathrm{P}$ & $\begin{array}{l}45 \%(95 \% \text { CI 36\%- } \\
54 \%)\end{array}$ & $\begin{array}{l}41 \%(95 \% \text { CI 29\%- } \\
53 \%)\end{array}$ \\
\hline $\begin{array}{l}\text { Manchikanti et al } \\
\text { (79) } 2000\end{array}$ & $3 / 5$ & $11 / 14$ & 200 & $\mathrm{P}$ & $\begin{array}{l}42 \%(95 \% \text { CI 35\%- } \\
49 \%)\end{array}$ & $\begin{array}{l}37 \%(95 \% \text { CI } 28 \%- \\
46 \%)\end{array}$ \\
\hline $\begin{array}{l}\text { Manchikanti et al } \\
\text { (80) } 2000\end{array}$ & $3 / 5$ & $10 / 14$ & 180 & $\mathrm{P}$ & $\begin{array}{l}\text { Average 36\% I: } 38 \% \\
\text { (CI 26\%-50\%) II: 32\% } \\
\text { (CI 20\%-44\%) III: } \\
38 \% \text { (CI 26\%-50\%) }\end{array}$ & $\begin{array}{l}\text { Average 25\% I: } 22 \% \text { (CI } \\
9 \%-35 \%) \text { II: } 27 \% \text { (CI } \\
\text { 13\%-41\%) III: } 27 \% \text { (CI } \\
13 \%-41 \%)\end{array}$ \\
\hline $\begin{array}{l}\text { Manchikanti et al } \\
\text { (82) } 2001\end{array}$ & $4 / 5$ & $10 / 14$ & 120 & $\mathrm{P}$ & $\begin{array}{l}40 \%(95 \% \text { CI } 31 \%, \\
49 \%)\end{array}$ & $\begin{array}{l}47 \% \text { (95\% CI 35\%, } \\
59 \%)\end{array}$ \\
\hline $\begin{array}{l}\text { Manchikanti et al } \\
\text { (126) } 2001\end{array}$ & $3 / 5$ & $8 / 14$ & $\begin{array}{c}\mathrm{Gp} \mathrm{I}(<65 \\
\text { years })=50 \mathrm{Gp} \text { II } \\
(>65 \text { years })=50\end{array}$ & $\mathrm{P}$ & $\begin{array}{l}\text { I: } 30 \% \text { CI } 17 \%-43 \%) \\
\text { II: } 52 \% \text { CI } 38 \%-66 \%)\end{array}$ & $\begin{array}{l}\text { I: } 26 \% \text { CI } 11 \%-40 \%) \text { II } \\
33 \% \text { CI } 14 \%-35 \%)\end{array}$ \\
\hline $\begin{array}{l}\text { Manchikanti et al } \\
\text { (127) } 2001\end{array}$ & $3 / 5$ & $7 / 14$ & $\begin{array}{c}\text { Gp I (no prior } \\
\text { surgery)=50 Gp II } \\
\text { (prior surgery) }=50\end{array}$ & $\mathrm{P}$ & $\begin{array}{l}\text { I: } 44 \% \text { (95\% CI 31\%- } \\
\text { 49\%) II: 32\% (95\% CI } \\
\text { 19\%-45\%) }\end{array}$ & $\begin{array}{l}\text { I: } 36 \% \text { (95\% CI } 18 \%- \\
54 \% \text { ) II: } 24 \% \text { ( } 95 \% \text { CI } \\
9 \%-38 \%)\end{array}$ \\
\hline $\begin{array}{l}\text { Manchikanti et al } \\
\text { (128) } 2001\end{array}$ & $3 / 5$ & $7 / 14$ & $\begin{array}{c}\mathrm{Gp} \mathrm{I} \\
(\mathrm{BMI}<30)=50 \mathrm{Gp} \\
\mathrm{II}(\mathrm{BMI}>30)=50\end{array}$ & $\mathrm{P}$ & $\begin{array}{l}\text { I: } 36 \% \text { (95\% CI } 22 \%- \\
50 \%) \text { II: } 40 \% \text { ( } 95 \% \text { CI } \\
26 \%-54 \%)\end{array}$ & $\begin{array}{l}\text { I: } 44 \% \text { (95\% CI } 26 \%- \\
61 \%) \text { II: } 33 \% \text { (95\% CI } \\
16 \%-51 \%)\end{array}$ \\
\hline $\begin{array}{l}\text { Manchikanti et al } \\
\text { (117) } 2002\end{array}$ & $3 / 5$ & $8 / 14$ & 120 & $\mathrm{P}$ & $\begin{array}{l}40 \%(95 \% \text { CI 31\%- } \\
49 \%)\end{array}$ & $\begin{array}{l}30 \%(95 \% \text { CI } 20 \%- \\
40 \%)\end{array}$ \\
\hline $\begin{array}{l}\text { Manchikanti et al } \\
\text { (116) } 2003\end{array}$ & $4 / 5$ & $9 / 14$ & $\begin{array}{l}\text { GI: Single region } \\
=150 \text { GII: multiple } \\
\text { regions }=150\end{array}$ & $\mathrm{P}$ & $\begin{array}{l}\text { I: } 21 \% \text { (95\% CI } 14 \%- \\
27 \%) \text { II : } 41 \%(95 \% \text { CI } \\
33 \%-49 \%)\end{array}$ & $\begin{array}{l}\text { I: } 17 \% \text { (95\% CI } 10 \%- \\
24 \%) \text { II : } 27 \% \text { (95\% CI } \\
18 \%-36 \%)\end{array}$ \\
\hline $\begin{array}{l}\text { Manchikanti et al } \\
\text { (118) } 2004\end{array}$ & $3 / 5$ & $11 / 14$ & 397 of 500 patients & $\mathrm{P}$ & $\begin{array}{l}31 \%(95 \% \text { CI 27\%- } \\
36 \%)\end{array}$ & $\begin{array}{l}27 \%(95 \% \text { CI 22\%- } \\
32 \%)\end{array}$ \\
\hline $\begin{array}{l}\text { Manchukonda et al } \\
\text { (131) } 2007\end{array}$ & $3 / 5$ & $9 / 14$ & 303 of 500 patients & $\mathrm{R}$ & $\begin{array}{l}27 \%(95 \% \text { CI 22\%- } \\
33 \%)\end{array}$ & $\begin{array}{l}45 \%(95 \% \text { CI 36\%- } \\
53 \%)\end{array}$ \\
\hline $\begin{array}{l}\text { Manchikanti et al } \\
\text { (132) } 2007\end{array}$ & $4 / 5$ & $12 / 14$ & 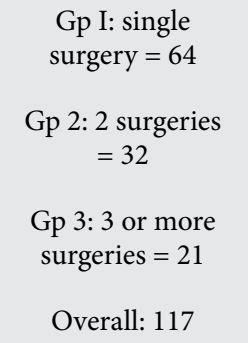 & $\mathrm{P}$ & $\begin{array}{l}14 \%(95 \% \text { CI } 5 \%-23 \%) \\
19 \%(95 \% \text { CI } 5 \%-33 \%) \\
19 \%(95 \% \text { CI } 2 \%-36 \%) \\
\begin{array}{l}\text { Overall: } 16 \%(95 \% \text { CI } \\
9 \%-23 \%)\end{array}\end{array}$ & $\begin{array}{l}49 \% \text { (95\% CI 36\%-63\%) } \\
50 \% \text { (95\% CI 30\%-70\%) } \\
47 \% \text { (95\% CI 23\%-71\%) } \\
\text { Overall: } 49 \% \text { (95\% CI } \\
39 \%-59 \%)\end{array}$ \\
\hline
\end{tabular}

$P=$ prospective $; B=$ single blind $R=$ retrospective 
Two new studies estimated false-positive rates of uncontrolled or single medial branch blocks $(131,132)$. The false-positive rates in these papers were within the range reported in previous studies (17\% to $47 \%$ in the lumbar spine, $27 \%$ to $63 \%$ in the cervical spine, and $42 \%$ to $58 \%$ in the thoracic spine).

The search for a clinical test/criterion to screen out subjects with a low probability of a positive analgesic response to diagnostic facet joint injections continues. More recently Laslett et al (111) revisited this issue and, using complicated statistical analysis, concluded that 7 clinical findings in 4 different combinations (CPR or clinical prediction rules) are highly sensitive in predicting a negative response to a single zygapophysial joint block at $95 \%$ pain reduction. Significant limitations of this study include exclusion of $20 \%$ subjects $(n=31)$ for various reasons such as failure to complete the study, and potential for selection bias in the absence of a randomized control design. Also it is not known how the authors resolved the issue of false-positives and false-negatives in this study. Two additional studies by the same authors $(113,147)$, one in German (with an abstract in English) reported a proportional chance statistic of $33 \%$ and a kappa of 0.31 for diagnostic agreement between clinical diagnoses and diagnoses based on available reference standards for known causes of LBP. Previous studies have attempted to identify reliable clinical predictors of positive or negative response to diagnostic facet injections $(87,88,107,108)$. Clinical studies by others however have failed to confirm the existence of valid clinical criteria for diagnosing facet joint pain $(80,91,109)$. The results shown by Laslett et al (111) need further scientific scrutiny and validation in clinical trials by other researchers. Currently there are no clinical criteria that can predict response to diagnostic facet joint injections.

Schwarzer et al $(89,91)$ had previously reported that imaging abnormalities as seen on CT scanning and bone scintigraphy correlate poorly with the clinical diagnosis of facet joint pain. In contrast to these data, Pneumaticos et al (112) suggest that bone scintigraphy with SPECT scan can identify patients with low back pain requiring facet joint injections. LBP patients randomized to receive facet joint injections based on a positive SPECT scan were compared with those who received facet joint injections as recommended by a referring physician. Thirteen of 15 patients with abnormal SPECT scan reported $>1$ SD pain score improvement at 1 month in contrast to 7 of 32 patients with a negative scan or no SPECT scan. The authors concluded that use of SPECT scans decreased the number of facet joints injected and resulted in a corresponding cost reduction of $\$ 326$ per patient. Scrutiny of this study revealed several flaws, the study objective to use SPECT scans to identify LBP patients who would benefit from facet joint injections was not accomplished, because a faulty injection technique was employed. Large volumes of intraarticular plus extraarticular local anesthetic and steroid injections were used. By injecting 3 times the recommended volumes and infiltrating inside and outside the facet joint, the authors performed an injection that cannot be considered a diagnostic injection. Future studies should control for meticulous technique, compare prognostic capability of SPECT scan to a known reference standard (in this case response to comparative control medial branch blocks), evaluate for specificity and sensitivity of the test, analyze data for false-positive and false-negative responses, and perform cost analysis in a randomized double blind fashion.

Use of sedation poses some potential diagnostic and safety issues. Administration of a sedative may slightly increase the likelihood of a false-positive response when compared to a placebo. There are some who recommend against the use of sedation while others believe that sedating patients, where they are relaxed enough to ensure comfort, but sufficiently aware to fully express pain responses, improves safety by preventing jerking movements during needle placement.

Manchikanti et al (150-153) evaluated the confounding influences of sedation on pain ratings in patients undergoing diagnostic facet injections in the lumbar and cervical spine in well designed studies. Although use of IV midazolam and/or fentanyl for conscious sedation may introduce a false-positive response in a small percentage of patients, this effect can be minimized and diagnostic validity of medial branch blocks maintained by using stringent criteria for positive analgesic response. They demonstrated that a small group of subjects display a false-positive response with IV sedation as well as with placebo. Application of $>80 \%$ pain reduction criterion standard instead of $>50 \%$ pain reduction decreased the falsepositive response from $15 \%$ to $10 \%$.

Ultrasound guided injections are used for regional blocks. There is interest in applying this technology in chronic pain. A few papers have described ultrasound guided facet joint and nerve injections in 
cadavers and human subjects. Some have attempted face validity studies by confirming needle placement with fluoroscopic or $\mathrm{CT}$ imaging. Although there are obvious benefits to using ultrasound guidance, there are insufficient data for critical analysis and conclusions.

The current consensus is that there is no association between the results of facet blocks and clinical findings including imaging studies. Diagnostic facet injection can access deep seated structures not reached by standard spine examination, are able to selectively and accurately target a specified joint or nerve, and have the ability to confirm or exclude a specified joint or structure as the source of pain (124). The results obtained with single blocks should be confirmed by using comparative controlled blocks. Uncontrolled local anesthetic blocks have a limited role in evaluating spinal pain.

Some criticize diagnostic facet injections for lack of a gold standard. A gold or criterion standard allows accurate determination of the specificity and sensitivity of a test and assesses the capacity of a diagnostic test to yield positive results when the clinical condition is present and negative results when the clinical condition is not present $(178,179)$. Tissue confirmation for presence or absence of disease is a commonly accepted criterion standard. There is no tissue diagnosis to confirm the presence or absence of pain. Hence, this reference standard cannot be applied to diagnostic facet joint nerve blocks. An alternative and acceptable reference standard applicable in such situations is abolition or reproduction of the patient's pain symptoms and stability of diagnosis on long-term follow-up (124). Pain provocation is considered to be ineffective in facet joint pain diagnosis (180). Consequently, controlled facet injection techniques are the standard for establishing the diagnosis of facet pain when performed in an accurate, reproducible, and optimal manner. These techniques have been critically analyzed in multiple controlled trials and the results replicated.

\section{Conclusion}

Diagnostic facet joint blocks are safe, valid and reliable. Based on review of available studies that met inclusion criteria, the strength of evidence for diagnostic facet injection techniques is unchanged i.e. there is strong evidence that controlled diagnostic blocks distinguish painful from painless facet joints in the diagnostic work up of chronic spinal pain.

\section{References}

1. Sehgal N, Shah RV, McKenzie-Brown A, Everett CR. Diagnostic utility of facet (zygapophysial) joint injections in chronic spinal pain: A systematic review of evidence. Pain Physician 2005; 8:211-224.

2. Bogduk N. The zygapophysial joints. In Clinical Anatomy of the Lumbar Spine and Sacrum, 3rd ed. Churchill Livingstone, New York, 2005, pp 29-38.

3. Fukui S, Ohseto K, Shiotani M, Ohno K, Karasawa H, Naganuma Y, Yuda Y. Referred pain distribution of the cervical zygapophyseal joints and cervical dorsal rami. Pain 1996; 68:79-83.

4. Dwyer A, Aprill C, Bogduk N. Cervical zygapophyseal joint pain patterns: A study in normal volunteers. Spine 1990; 15:453-457.

5. Aprill C, Dwyer A, Bogduk N. The prevalence of cervical zygapophyseal joint pain patterns II: A clinical evaluation. Spine 1990; 15:458-461.

6. Pawl RP. Headache, cervical spondylosis, and anterior cervical fusion. Surg Ann 1977; 9:391-498.
7. Windsor RE, Nagula D, Storm S. Electrical stimulation induced cervical medial branch referral patterns. Pain Physician 2003; 6:411-418.

8. Dreyfuss P, Tibiletti C, Dreyer SJ. Thoracic zygapophyseal joint pain patterns: A study in normal volunteers. Spine 1994; 19:807-811.

9. Fukui S, Ohseto K, Shiotani M. Patterns of pain induced by distending the thoracic zygapophyseal joints. Reg Anesth 1997; 22:332-336.

10. Mooney V, Robertson J. The facet syndrome. Clin Orthop 1976; 115:149-156.

11. McCall IW, Park WM, O’Brien JP. Induced pain referral from posterior elements in normal subjects. Spine 1979; 4:441446.

12. Marks R. Distribution of pain provoked from lumbar facet joints and related structures during diagnostic spinal infiltration. Pain 1989; 39:37-40.

13. Fukui S, Ohseto K, Shiotani M, Ohno K, Karasawa H, Naganuma Y. Distribution of referral pain from the lumbar zygapophyseal joints and dorsal rami. Clin J Pain 1997; 13:303-307.
14. Hirsch C, Ingelmark BE, Miller M. The anatomical basis for low back pain. Acta Orthop Orthop Scand 1963; 33:1-17.

15. Windsor RE, King FJ, Roman SJ, Tata N, Cone-Sullivan LA, Thampi S, Acebey M, Gilhool JJ, Rao R, Sugar R. Electrical Stimulation Induced Lumbar Medial Branch Referral Patterns. Pain Physician 2002; 5:347-353.

16. Bogduk N. The clinical anatomy of the cervical dorsal rami. Spine 1982; 7:319330.

17. Cavanaugh JM, Ozaktay AC, Yamashita T, Avramov A, Getchell TV, King Al. Mechanisms of low back pain: A neurophysiologic and neuroanatomic study. Clin Orthop 1997; 335:166-180.

18. Bogduk N, Wilson AS, Tynan W. The human lumbar dorsal rami. J Anat 1982; 134:383-397.

19. Ohtori S, Takahashi K, Chiba T, Yamagata M, Sameda H, Moriya H. Sensory innervation of the cervical facet joints in rats. Spine 2001; 26:147-150.

20. Chua WH, Bogduk N. The surgical anatomy of thoracic facet denervation. Acta Neurochir 1995; 136:140-144. 
21. Barnsley L, Bogduk N. Medial branch blocks are specific for the diagnosis of cervical zygapophyseal joint pain. Reg Anesth 1993; 18:343-350.

22. Zhang J, Tsuzuki N, Hirabayashi S, Saiki K, Fujita K. Surgical anatomy of the nerves and muscles in the posterior cervical spine. Spine 2003; 1379-1384.

23. Dreyfuss P, Schwarzer AC, Lau P, Bogduk N. Specificity of lumbar medial branch and $L_{5}$ dorsal ramus blocks. Spine 1997; 22:895-902.

24. Kaplan M, Dreyfuss P, Halbrook B, Bogduk $\mathrm{N}$. The ability of lumbar medial branch blocks to anesthetize the zygapophysial joint. Spine 1998; 23:1847-1852.

25. Özaktay AC, Yamashita T, Cavanaugh $J M$, King Al. Fine nerve fibers and endings in the fibrous capsule of the lumbar facet joint. Trans Orthop Res Soc 1991; 16:353.

26. Ishikawa $\mathrm{T}$, Miyagi M, Ohtori S, Aoki Y, Ozawa T, Doya H, Saito T, Moriya H, Takahashi K. Characteristics of sensory DRG neurons innervating the lumbar facet joints in rats. Eur Spine J 2005; 14:559-564.

27. Suseki K, Takahashi Y, Takahashi K, Chiba T, Tanaka K, Morinaga T, Nakamura $\mathrm{S}$, Moriya $\mathrm{H}$. Innervation of the lumbar facet joints. Origins and functions. Spine 1997 ; 22:477-485.

28. Sameda H, Takahashi Y, Takahashi K, Chiba T, Ohtori S, Moriya H. Primary sensory neurons with dichotomizing axons projecting to the facet joint and the sciatic nerve in rats. Spine 2001; 26:1105-1109.

29. Yamada H, Honda T, Kikuchi S, Sugiura Y. Direct innervation of sensory fibers from the dorsal root ganglion of the cervical dura mater of rats. Spine 1998; 23:1524-1529.

30. Johnson GM. The sensory and sympathetic nerve supply within the cervical spine: review of recent observations. Man Ther 2004; 9:71-76.

31. Yoganandan N, Knowles SA, Maiman DJ, Pintar FA. Anatomic study of the morphology of human cervical facet joint. Spine 2003; 28:2317-2323.

32. Konnai Y, Honda T, Sekiguchi Y, Kikuchi $S$, Sugiura Y. Sensory innervation of the lumbar dura mater passing through the sympathetic trunk in rats. Spine 2000; 25:776-782.

33. Masini M, Paiva WS, Araujo AS Jr. Anatomical description of the facet joint innervation and its implication in the treatment of recurrent back pain. J Neurosurg Sci 2005; 49:143-146.

34. Ahmed M, Bjurholm A, Kreicbergs A,
Schultzberg M. Sensory and autonomic innervation of the facet joint in the rat lumbar spine. Spine 1993; 18:2121-2126.

35. Cavanaugh JM, Lu Y, Chen C, Kallakuri $\mathrm{S}$. Pain generation in lumbar and cervical facet joints. I Bone Joint Surg Am 2006; 88 Suppl 2:63-67.

36. Inami S, Shiga T, Tsujino A, Yabuki T, Okado N, Ochiai N. Immunohistochemical demonstration of nerve fibers in the synovial fold of the human cervical facet joint. J Orthop Res 2001; 19:593-596.

37. Kallakuri S, Singh A, Chen C, Cavanaugh JM. Demonstration of substance P, calcitonin gene-related peptide, and protein gene product 9.5 containing nerve fibers in human cervical facet joint capsules. Spine 2004; 29:1182-1186.

38. Chen C, Lu Y, Kallakuri S, Patwardhan A, Cavanaugh JM. Distribution of Adelta and $\mathrm{C}$-fiber receptors in the cervical facet joint capsule and their response to stretch. J Bone Joint Surg Am 2006; 88:1807-1816.

39. Ohtori S, Takahashi K, Moriya H. Calcitonin gene-related peptide immunoreactive DRG neurons innervating the cervical facet joints show phenotypic switch in cervical facet injury in rats. Eur Spine J 2003; 12:211-215.

40. Miyagi M, Ohtori S, Ishikawa T, Aoki Y, Ozawa T, Doya H, Saito T, Moriya H, Takahashi K. Up-regulation of TNFalpha in DRG satellite cells following lumbar facet joint injury in rats. Eur Spine J 2006; 15:953-958.

41. Ohtori S, Takahashi K, Chiba T, Yamagata M, Sameda H, Moriya H. Substance $\mathrm{P}$ and calcitonin gene-related peptide immunoreactive sensory DRG neurons innervating the lumbar facet joints in rats. Auton Neurosci 2000; 86:13-17.

42. Suseki K, Takahashi Y, Takahashi K, Chiba T, Tanaka K, Moriya H. CGRP-immunoreactive nerve fibers projecting to lumbar facet joints through the paravertebral sympathetic trunk in rats. Neurosci Lett 1996; 221:41-44.

43. Ohtori S, Moriya H, Takahashi K. Calcitonin gene-related peptide immunoreactive sensory DRG neurons innervating the cervical facet joints in rats. J Orthop Sci 2002; 7:258-261.

44. Ohtori S, Takahashi K, Chiba T, Yamagata M, Sameda H, Moriya H. Brain-derived neurotrophic factor and vanilloid receptor subtype 1 immunoreactive sensory DRG neurons innervating the lumbar facet joints in rats. Auton Neurosci 2001; 94:132-135.

45. McLain RF, Pickar JG. Mechanoreceptor endings in human thoracic and lumbar facet joints. Spine 1998; 23:168-173.

46. McLain RF. Mechanoreceptors ending in human cervical facets joints. Spine 1994; 5:495-501.

47. Yamashita T, Cavanaugh JM, el-Bohy AA, Getchell TV, King Al. Mechanosensitive afferent units in the lumbar facet joint. J Bone Joint Surg (Am) 1990; 72:865-870.

48. Yamashita T, Cavanaugh JM, Ozaktay AC, Avramov Al, Getchell TV, King Al. Effect of substance $P$ on mechanosensitive units of tissues around and in the lumbar facet joint. J Orthop Res 1993; 11:205-214.

49. Beaman DN, Graziano GP, Glover RA, Wojtys EM, Chang V. Substance P innervation of lumbar spine facet joints. Spine 1993; 18:1044-1049.

50. Ohtori S, Takahashi K, Chiba T, Yamagata M, Sameda H, Moriya H. Phenotypic inflammation switch in rats shown by calcitonin gene-related peptide immunoreactive dorsal root ganglion neurons innervating the lumbar facet joints. Spine 2001; 26:1009-1013.

51. Chen C, Lu Y, Cavanaugh JM, Kallakuri S, Patwardhan A. Recording of neural activity from goat cervical facet joint capsule using custom-designed miniature electrodes. Spine 2005; 30:13671372.

52. Lu Y, Chen C, Kallakuri S, Patwardhan $A$, Cavanaugh JM. Development of an in vivo method to investigate biomechanical and neurophysiological properties of spine facet joint capsules. Eur Spine J 2005; 14:565-572.

53. Lu Y, Chen C, Kallakuri S, Patwardhan A, Cavanaugh JM. Neurophysiological and biomechanical characterization of goat cervical facet joint capsules. J Orthop Res 2005; 23:779-787.

54. Mayer TG, Gatchel RJ, Keeley J, McGeary D, Dersh J, Anagnostis C. A randomized clinical trial of treatment for lumbar segmental rigidity. Spine 2004; 29:2199-2205.

55. El-Bohy AA, Goldberg SJ, King Al. Measurement of facet capsular stretch. In Proceedings of the American Society of Mechanical Engineers, Bioengineering Symposium; New York, NY, Jun 14-17, 1987, pp 161-164.

56. Yang KH, King Al. Mechanism of facet load transmission as a hypothesis for low-back pain. Spine 1984; 9:557-565.

57. Borchgrevink GE, Smevik O, Nordby A, Rinck PA, Stiles TC, Lereim I. MR imaging and radiography of patients with cervical hypertension-flexion injuries after car accidents. Acta Radiol 1995; 
36:425-428.

58. Ronnen HR, de Korte PJ, Brink PR, van der Bijl HJ, Tonino AJ, Franke CL. Acute whiplash injury: is there a role for MR imaging? - A prospective study of 100 patients. Radiology 1996; 201:93-96.

59. Pennie B, Agambar L. Patterns of injury and recovery in whiplash. Injury 1991; 22:57-59.

6o. Siegmund GP, Myers BS, Davis MB, Bohnet HF, Winkelstein BA. Human cervical motion segment flexibility and facet capsular ligament strain under combined posterior shear, extension and axial compression. Stapp Car Crash $J$ 2000; 44:159-170.

61. Winkelstein BA, Nightingale RW, Richardson WJ, Myers BS. Cervical facet joint mechanics: its application to whiplash injury. Stapp Car Crash J 1999; 43:243-252.

62. Onan OA, Heggeness MH, Hipp JA. A motion analysis of the cervical facet joint. Spine 1998; 23:430-439.

63. Stemper BD, Yoganandan N, Pintar FA. Gender- and region-dependent local facet joint kinematics in rear impact: implications in whiplash injury. Spine 2004; 29:1764-1771.

64. Keeley J, Mayer T, Cox R, Gatchel RJ, Smith J, Mooney V. Quantification of lumbar function: Part 5. Reliability of range of motion measures in the sagittal plane and an in vivo torso rotation measurement technique. Spine 1986; 11:31-35.

65. Mayer T, Robinson R, Pegues P, Kohles $S$, Gatchel RJ. Lumbar segmental rigid ity: can its identification with facet injections and stretching exercises be useful? Arch Phys Med Rehabil 2000; 81:1143-1150.

66. Boswell MV, Shah RV, Everett CR, Sehgal N, Mckenzie-Brown AM, Abdi S, Bowman RC, Deer TR, Datta S, Colson JD, Spillane WF, Smith HS, LucasLevin LF, Burton AW, Chopra P, Staats PS, Wasserman RA, Manchikanti L. Interventional techniques in the management of chronic spinal pain: Evidencebased practice guidelines. Pain Physician 2005; 8:1-47.

67. Manchikanti L, Staats PS, Singh V, Schultz DM, Vilims BD, Jasper JF, Kloth DS, Trescot AM, Hansen HC, Falasca TD, Racz GB, Deer T, Burton AW, Helm $\mathrm{S}$, Lou L, Bakhit CE, Dunbar EE, Atlurì SL, Calodney AK, Hassenbusch S, Feler CA. Evidence-based practice guidelines for interventional techniques in the management of chronic spinal pain. Pain Physician 2003; 6:3-80.
68. Deyo RA, Weinstein JN. Low back pain. N Engl J Med 2001; 344:363-370.

69. Kirwan EO. Back pain. In Wall PD, Melzack R (eds.) Text Book of Pain, 2nd ed. Churchill Livingstone, Edinburgh, 1989, pp 335-340.

70. Deyo RA, Rainville J, Kent DL. What can the history and physical examination tell us about low back pain? JAMA 1992; 268:760-765.

71. Bogduk N, McGuirk B. Causes and sources of chronic low back pain. In Bogduk N, McGuirk B (eds). Medical Management of Acute and Chronic Low Back Pain. An Evidence-Based Approach: Pain Research and Clinical Management. Elsevier Science BV, Amsterdam, 2002; 13:115-126.

72. Bogduk N, McGuirk B. An algorithm for precision diagnosis. In Bogduk N, McGuirk B (eds.) Medical Management of Acute and Chronic Low Back Pain. An Evidence-Based Approach: Pain Research and Clinical Management. Elsevier Science BV, Amsterdam, 2002; 13:177-186.

73. Bogduk N. Low back pain. In Clinical Anatomy of the Lumbar Spine and Sacrum, 4th ed. Churchill Livingstone, New York, 2005 pp 183-216.

74. Bogduk N. International Spinal Injection Society guidelines for the performance of spinal injection procedures. Part 1: Zygapophyseal joint blocks. Clin J Pain 1997; 13:285-302.

75. Boswell MV, Singh V, Staats PS, Hirsch JA. Accuracy of precision diagnostic blocks in the diagnosis of chronic spinal pain of facet or zygapophysial joint origin. Pain Physician 2003; 6:449-456.

76. Bogduk N, Lord S. Cervical zygapophysial joint pain. Neurosurgery 1998; 8:107-117.

77. Schwarzer AC, Aprill CN, Derby R, Fortin J, Kine G, Bogduk N. Clinical features of patients with pain stemming from the lumbar zygapophysial joints. Is the lumbar facet syndrome a clinical entity? Spine 1994; 19:1132-1137.

78. Manchikanti L, Pampati V, Fellows B, Pakanati RR. Prevalence of lumbar facet joint pain in chronic low back pain. Pain Physician 1999; 2:59-64.

79. Manchikanti L, Pampati V, Fellows B, Baha A. The inability of the clinical picture to characterize pain from facet joints. Pain Physician 2000; 3:158-166.

80. Manchikanti L, Pampati V, Fellows B, Bakhit C. The diagnostic validity and therapeutic value of medial branch blocks with or without adjuvants. Curr Rev Pain 2000; 4:337-344.

81. Schwarzer AC, Wang SC, Bogduk N, Mc-
Naught PJ, Laurent R. Prevalence and clinical features of lumbar zygapophysial joint pain: A study in an Australian population with chronic low back pain. Ann Rheum Dis 1995; 54:100-106. .

82. Manchikanti L, Singh V, Pampati V, Damron K, Barnhill R, Beyer C, Cash K. Evaluation of the relative contributions of various structures in chronic low back pain. Pain Physician 2001; 4:308-316. .

83. Barnsley L, Lord SM, Wallis BJ, Bogduk $\mathrm{N}$. The prevalence of chronic cervical zygapophyseal joint pain after whiplash. Spine 1995; 20:20-26.

84. Lord SM, Barnsley L, Wallis BJ, Bogduk N. Chronic cervical zygapophysial joint pain with whiplash: A placebo-controlled prevalence study. Spine 1996; 21:17371745.

85. Bogduk N, McGuirk B. Precision diagnosis. In Medical Management of Acute and Chronic Low Back pain. An Evidence-Based Approach: Pain Research and Clinical Management. Elsevier Science BV, Amsterdam 2002; 13:169-176.

86. Bogduk N, McGuirk B. Assessment. In Medical Management of Acute and Chronic Low Back pain. An EvidenceBased Approach: Pain Research and Clinical Management. Elsevier Science BV, Amsterdam, 2002; 13:127-138. .

87. Bogduk N, McGuirk B. Medical Management of Acute and Chronic Low Back Pain. An Evidence-Based Approach: Pain Research and Clinical Management. Amsterdam: Elsevier Science BV, 2002.

88. Bogduk N, McGuirk B. Management of Acute and Chronic Neck Pain. An Evidence-Based Approach. Elsevier, 2006.

89. Schwarzer AC, Scott AM, Wang SC, Hoschl R, Wiseman JC, Copper RA. The role of bone scintigraphy in chronic low back pain: A comparison of SPECT and planar images and zygapophysial joint injection. Aust NZJ Med 1992; 22:185.

90. Raymond J, Dumas JM. Intraarticular facet block: Diagnostic tests or therapeutic procedure? Radiology 1989; 151:333-336.

91. Schwarzer AC, Derby R, Aprill CN, Fortin J, Kine G, Bogduk N. Pain from the lumbar zygapophysial joints: A test of two models. J Spinal Disord 1994; 7:331-336.

92. Jackson RP, Jacobs RR, Montesano PX. Facet joint injection in low back pain. A prospective statistical study. Spine 1988; 13:966-971.

93. Jackson RP. The facet syndrome: Myth or reality? Clin Orthop 1992; 279:110-121.

94. Jonsson $H$, Bring $G$, Rauschning $W$, Sahlstedt B. Hidden cervical spine inju- 
ries in traffic accident victims with skull fractures. J Spinal Dis 1991; 4:251-263.

95. Taylor JR, Twomey LT. Acute injuries to cervical joints: An autopsy study of neck sprain. Spine 1993; 9:1115-1122.

96. Schwarzer AC, Wang SC, O’Driscoll D, Harrington $T$, Bogduk N, Laurent $R$. The ability of computed tomography to identify a painful zygapophysial joint in patients with chronic low back pain. Spine 1995; 20:907-912.

97. Binet EF, Moro JJ, Marangola JP, Hodge C). Cervical spine tomography in trauma. Spine 1977; 2:163-172.

98. Abel MS. Occult traumatic lesions of the cervical vertebrae. Critical Rev Clin Radiol Nuclear Med 1975; 6:469-553.

99. Woodring JH, Goldstein SJ. Fractures of the articular processes of the cervical spine. Am / Roentgenol 1982; 139:341344 .

100. Magora A, Bigos SJ, Stolov WC, Toms li MA, Magora F, Vatine JJ. The significance of medical imaging findings in low back pain. Pain Clinic 1994; 7:99105.

101. Murtagh FR. Computed tomography and fluoroscopy guided anesthesia and steroid injection in facet syndrome. Spine 1988; 13:686-689.

102. Faye LJ, Wiles MR. Manual examination of the spine. In Haldeman S (ed). Principles and Practice of Chiropractic. 2nd ed. Appleton \& Lange, San Mateo, 1992, pp 301-318.

103. Destouet JM, Gilula LA, Murphy WA, Monsees B. Lumbar facet joint injection: Indication, technique, clinical correlation and preliminary results. Radiology 1982; 145:321-325.

104. Moran R, O'Connell D, Walsh MG. The diagnostic value of facet joint injections. Spine 1988; 13:1407-1410.

105. Dory MA. Arthrography of the cervical facet joints. Radiology 1983; 148:379382.

106. Dory MA. Arthrography of the lumbar facet joints. Radiology 1981; 140:23 27.

107. Revel ME, Listrat VM, Chevalier XJ, Dougados M, N'guyen MP, Vallee C, Wybier M, Gires F, Amor B. Facet joint block for low back pain: Identifying predictors of a good response. Arch Phys Med Rehabil 1992; 73:824-828.

108. Revel M, Poiraudeau S, Auleley GR, Payan C, Denke A, Nguyen M, Chevrot A, Fermanian J. Capacity of the clinical picture to characterize low back pain relieved by facet joint anesthesia. Proposed criteria to identify patients with painful facet joints. Spine 1998;
23:1972-1977.

109. Laslett M, Oberg B, Aprill CN, McDonald B. Zygapophysial joint blocks in chronic low back pain: a test of Revel's model as a screening test. BMC Musculoskelet Disord 2004; 5:43.

110. Young S, Aprill C, Laslett M. Correlation of clinical examination characteristics with three sources of chronic low back pain. Spine J 2003; 3:460-465.

111. Laslett M, McDonald B, Aprill CN, Tropp H, Oberg B. Clinical predictors of screening lumbar zygapophyseal joint blocks: development of clinical prediction rules. Spine J 2006; 6:370-379.

112. Pneumaticos SG, Chatziioannou SN, Hipp JA, Moore WH, Esses SI. Low back pain: prediction of short-term outcome of facet joint injection with bone scintigraphy. Radiology 2006; 238: 693698

113. Laslett M, McDonald B, Tropp H, Aprill $\mathrm{CN}$, Oberg B. Agreement between diag. noses reached by clinical examination and available reference standards: a prospective study of 216 patients with lumbopelvic pain. BMC Musculoskelet Disord 2005; 6:28.

114. Barnsley L, Lord S, Bogduk N. Comparative local anesthetic blocks in the diagnosis of cervical zygapophysial joints pain. Pain 1993; 55:99-106.

115. Lord SM, Barnsley L, Bogduk N. The utility of comparative local anesthetic blocks versus placebo-controlled blocks for the diagnosis of cervical zyg apophysial joint pain. Clin J Pain 1995; 11:208-213..

116. Manchikanti L, Hirsch JA, Pampati V. Chronic low back pain of facet (zyg. apophysial) joint origin: Is there a difference based on involvement of single or multiple spinal regions? Pain Physician 2003; 6:399-405.

117. Manchikanti L, Singh V, Pampati V, Damron K, Beyer C, Barnhill R. Is there correlation of facet joint pain in lumbar and cervical spine? An evaluation of prevalence in combined chronic low back and neck pain. Pain Physician 2002; 5:365-371.

118. Manchikanti L, Boswell MV, Singh V, Pampati V, Damron KS, Beyer CD. Prevalence of facet joint pain in chronic spinal pain of cervical, thoracic, and lumbar regions. BMC Musculoskelet Disord 2004; 5:15.

119. Manchikanti L, Singh V, Pampati V, Beyer C, Damron K. Evaluation of the prevalence of facet joint pain in chronic thoracic pain. Pain Physician 2002; 5:354-359.

120. Manchikanti L, Singh V, Rivera J, Pam- pati V. Prevalence of cervical facet joint pain in chronic neck pain. Pain Physician 2002; 5:243-249. .

121. North RB, Kidd DH, Zahurak M, Piantadosi S. Specificity of diagnostic nerve blocks: A prospective, randomized study of sciatica due to lumbosacral spine disease. Pain 1996; 65:77-85.

122. Hogan QH, Abram SE. Neural blockade for diagnosis and prognosis. Anesthesiology 1997; 86:216-241.

123. Hildebrandt J. Relevance of nerve blocks in treating and diagnosing low back pain - is the quality decisive? Schmerz 2001; 15:474-483.

124. Saal JS. General principles of diagnostic testing as related to painful lumbar spine disorders. Spine 2002; 27:25382545.

125. Barnsley L, Lord S, Wallis B, Bogduk N. False-positive rates of cervical zygapophysial joint blocks. Clin J Pain 1993; 9:124-130.

126. Manchikanti L, Pampati V, Rivera J, Fellows B, Beyer C, Damron K. Role of facet joints in chronic low back pain in the elderly: A controlled comparative prevalence study. Pain Practice 2001; 1:332-337.

127. Manchikanti L, Pampati V, Baha A, Fellows B, Damron KS, Barnhill RC. Contribution of facet joints to chronic low back pain in postlumbar laminectomy syndrome: A controlled comparative prevalence evaluation. Pain Physician 2001; 4:175-180. .

128. Manchikanti L, Pampati V, Singh V, Beyer CD, Damron KS, Fellows B. Evaluation of the role of facet joints in persistent low back pain in obesity: A controlled, prospective, comparative evaluation. Pain Physician 2001; 4:266-272.

129. Schwarzer AC, Aprill CN, Derby R, Fortin J, Kine G, Bogduk N. The false-positive rate of uncontrolled diagnostic blocks of the lumbar zygapophysial joints. Pain 1994; 58:195-200.

130. Ackerman WE, Munir MA, Zhang JM, Ghaleb A. Are diagnostic lumbar facet injections influenced by pain of muscular origin? Pain Practice 2004; 4:286291.

131. Manchukonda R, Manchikanti KN, Cash KA, Pampati V, Manchikanti L. Facet joint pain in chronic spinal pain: an evaluation of prevalence and false-positive rate of diagnostic blocks. J Spinal Disord Tech 2007; in press.

132. Manchikanti L, Manchukonda R, Pampati V, Damron KS, McManus CD. Prevalence of facet joint pain in chronic low back pain in post surgical patients by 
controlled comparative local anesthetic blocks. Arch Phys Med Rehabil 2007; in press.

133. Bonica JJ, Buckley FP. Regional analgesia with local anesthetics. In Bonica JJ (ed). The Management of Pain. Lea \& Febiger, Philadelphia, 1990; 2:1883. 1966.

134. Boas RA. Nerve blocks in the diagnosis of low back pain. Neurosurg Clin North Am 1991; 2:806-816.

135. Leonardi M, Pfirrmann CW, Boos N. Injection studies in spinal disorders. Clin Orthop Relat Res 2006; 443:168-182.

136. Waggershauser T, Schwarzkopf S, Reiser M. Facet blockade, peridural and periradicular pain therapy. Radiologe 2006; 46:520-526.

137. Resnick DK, Choudhri TF, Dailey AT, Groff MW, Khoo L, Matz PG, Mummaneni P, Watters WC 3rd, Wang J, Walters $\mathrm{BC}$, Hadley MN; American Association of Neurological Surgeons/Congress of Neurological Surgeons. Guidelines for the performance of fusion procedures for degenerative disease of the lumbar spine. Part 13: injection therapies, lowback pain, and lumbar fusion. J Neurosurg Spine. 2005; 2:707-715.

138. Nachemson A, Vingård E. Assessment of patients with neck and back pain: A best evidence synthesis. In Nachemson A, Vingård E (eds). Neck and Back Pain. The Scientific Evidence of Causes, Diagnosis and Treatment. Lippincott Williams \& Wilkins, Philadelphia, 2000, pp 189-236.

139. Ramsey SD, Luce BR, Deyo R, Franklin $\mathrm{G}$. The limited state of technology assessment for medical devices: Facing the issues. Am J Managed Care 1998; 4:188-199.

140. Bogduk N, McGuirk B. Precision treatment. In Bogduk N, McGuirk B (eds). Medical Management of Acute and Chronic Low Back Pain. An EvidenceBased Approach: Pain Research and Clinical Management, Vol. 13, Elsevier Science BV, Amsterdam, 2002, pp 187198.

141. Bogduk N, McGuirk B. An approach to chronic low back pain. In Bogduk N, McGuirk B (eds). Medical Management of Acute and Chronic Low Back Pain. An Evidence-Based Approach: Pain Research and Clinical Management, Vol. 13. Elsevier Science BV, Amsterdam, 2002, pp 199-204.

142. Merskey H, Bogduk N. Classification of chronic pain. In Descriptions of Chronic Pain Syndromes and Definition of Pain Terms, 2nd ed. IASP Press, Seat- tle, 1994, pp 180-181.

143. West S, King V, Carey T, Lohr K, McKoy N, Sutton S, Lux L. Systems to rate the strength of scientific evidence. Evidence Report/Technology Assessment No. 47 University of North Carolina: Agency for Healthcare Research and Quality. AHRQ Publication No. 02-E016; April 2002.

144. Whiting P, Rutjes A, Reitsma J, Bossuyt P, Kleijnen J. The Development of QUADAS: A tool for the quality assessment of studies of diagnostic accuracy included in systematic reviews. BMC Med Res Methodol 2003; 3:25.

145. Chakraverty R, Dias R. Audit of conservative management of chronic low back pain in a secondary care setting-part I: facet joint and sacroiliac joint interventions. Acupunct Med 2004; 22 207-213.

146. Cohen SP, Hurley RW, Christo PJ, Winkley J, Mohiuddin, MM, Stojanovic, MP. Clinical predictors of success and failure for lumbar facet radiofrequency denervation. Clin J Pain 2007; 23:45-52.

147. Laslett M, McDonald B, Tropp H, Aprill $\mathrm{CN}$, Oberg B. Agreement between diagnoses reached by clinical examination and available reference standards: A prospective study of 216 patients with lumbopelvic pain [German]. Manuelle Therapie 2006; 10:140-151.

148. Houseni M, Chamroonrat W, Zhuang $\mathrm{H}$, Alavi A. Facet joint arthropathy demonstrated on FDG-PET. Clin Nucl Med 2006; 31:418-419.

149. Kim KA, Wang MY. Magnetic resonance image-based morphological predictors of single photon emission computed tomography-positive facet arthropathy in patients with axial back pain. Neurosurgery 2006; 9:147-156.

150. Manchikanti L, Pampati V, Damron KS, MCManus CD, Jackson SD, Barnhill RC, Martin JC. A randomized, prospective, double-blind, placebo-controlled evaluation of the effect of sedation on diagnostic validity of cervical facet joint pain. Pain Physician 2004; 7:301-310.

151. Manchikanti L, Damron KS, Rivera J, McManus CD, Jackson SD, Barnhill RC, Martin JC. Evaluation of effect of sedation as a confounding factor in the diagnostic validity of lumbar facet joint pain: A prospective, randomized, double-blind, placebocontrolled evaluation. Pain Physician 2004; 7:411-417.

152. Manchikanti L, Pampati V, Damron KS, McManus CD, Jackson SD, Barnhill RC, Martin JC. The effect of sedation on diagnostic validity of facet joint nerve blocks: An evaluation to assess similarities in population with involvement in cervical and lumbar regions. Pain Physician 2006; 9:47-52.

153. Manchikanti L, Pampati V, Damron K. The role of placebo and nocebo effects of perioperative administration of sedatives and opioids in interventional pain management. Pain Physician 2005; 8:349-355.

154. Manchikanti L, Pampati V, Fellows B, Rivera JJ, Damron KS, Beyer CD. Influence of psychological factors on the ability of diagnose chronic low back pain of facet joint origin. Pain Physician 2001; 4:349-357.

155. Heckmann JG, Maihofner C, Lanz S, Rauch C, Neundorfer B. Transient tetraplegia after cervical facet joint injection for chronic neck pain administered without imaging guidance. Clin Neurol Neurosurg 2006; 108: 709-711.

156. Speldewinde GC, Bashford GM, Davidson IR. Diagnostic cervical zygapophyseal joint blocks for chronic cervical pain. Med J Aust 2001; 174:174-176.

157. Falagas ME, Bliziotis IA, Mavrogenis AF, Papagelopoulos PJ. Spondylodiscitis after facet joint steroid injection: A case report and review of the literature. Scand J Infect Dis 2006; 38:295299.

158. Weingarten TN, Hooten WM, Huntoon MA. Septic facet joint arthritis after a corticosteroid facet injection. Pain Med 2006; 7:52-56

159. Okada F, Takayama H, Doita M, Harada T, Yoshiya S, Kurosaka M. Lumbar facet joint infection associated with epidural and paraspinal abscess: a case report with review of the literature. I Spinal Disord Tech 2005; 18:458-461.

160. Gaul C, Neundorfer B, Winterholler M. latrogenic (para-) spinal abscesses and meningitis following injection therapy for low back pain. Pain. 2005; 116:407410.

161. Dizdar O, Alyamac E, Onal IK, Uzun O. Group B streptococcal facet joint arthritis: Case report. Spine 2005; 30: E414-E416.

162. Daivajna S, Jones A, O'Malley M, Mehdian $\mathrm{H}$. Unilateral septic arthritis of a lumbar facet joint secondary to acupuncture treatment-a case report. Acupunct Med 2004; 22:152-155.

163. Manchikanti L, Singh V, Pampati S. Are diagnostic lumbar medial branch blocks valid? Results of 2-year followup. Pain Physician 2003; 5:147-153.

164. Manchikanti L, Pampati V, Bakhit CE, Rivera JJ, Beyer CD, Damron KS, Barn- 
hill RC. Effectiveness of lumbar facet joint nerve blocks in chronic low back pain: A randomized clinical trial. Pain Physician 2001; 4:101-117.

165. Manchikanti L, Manchikanti KN, Damron KS, Pampati V. Effectiveness of cervical medial branch blocks in chronic neck pain: A prospective outcome study. Pain Physician 2004; 7:195-202.

166. Boswell MV, Colson JD, Spillane WF. Therapeutic facet joint interventions: A systematic review of their role in chronic spinal pain management and complications. Pain Physician 2005; 8:101114 .

167. Manchikanti L, Singh V, Vilims BD, Hansen HC, Schultz DM, Kloth DS. Medial branch neurotomy in management of chronic spinal pain: Systematic review of the evidence. Pain Physician 2002; 5:405-418.

168. Lord SM, Barnsley L, Wallis BJ, McDonald GJ, Bogduk N. Percutaneous radiofrequency neurotomy for chronic cervical zygapophyseal-joint pain. $N$ Engl J Med 1996; 335:1721-1726.

169. Dreyfuss P, Halbrook B, Pauza K, Joshi A, McLarty J, Bogduk N. Efficacy and validity of radiofrequency neurotomy for chronic lumbar zygapophysial joint pain. Spine 2000; 25:1270-1277.

170. Van Kleef M, Barendse GAM, Kessels A,
Voets HM, Weber WE, de Lange S. Randomized trial of radiofrequency lumbar facet denervation for chronic low back pain. Spine 1999; 24:1937-1942.

171. Manchikanti L, Manchikanti KN, Manchukonda R, Pampati V, Cash KA. Evaluation of therapeutic thoracic medial branch block effectiveness in chronic thoracic pain: A prospective outcome study with minimum 1-year follow up. Pain Physician 2006; 9:97-105.

172. Manchikanti L, Manchukonda R, Cash KA, Damron KS, Pampati V, McManus $C D$. Evaluation of lumbar facet joint nerve blocks in the management of chronic low back pain: A preliminary report of a randomized, double-blind controlled trial. Clinical Trial NCTo0355914. BMC Musculoskelet Disord 2006; in press.

173. Leclaire R, Fortin L, Lambert R, Bergeron YM, Rossignol M. Radiofrequency facet joint denervation in the treatment of low back pain: a placebo-controlled clinical trial to assess efficacy. Spine 2001; 26:1411-1416.

174. van Wijk RM, Geurts JW, Wynne HJ, Hammink E, Buskens E, Lousberg R, Knape JT, Groen GJ. Radiofrequency denervation of lumbar facet joints in the treatment of chronic low back pain: a randomized, double-blind, sham lesion-controlled trial. Clin J Pain 2005;
21:335-344

175. Dreyfuss $P$, Baker R, Leclaire R, Fortin L, Lambert R, Bergeron Y, Rossignol M. Radiofrequency facet joint denervation in the treatment of low back pain: a placebo-controlled clinical trial to assess efficacy. Spine 2002; 27:556-557.

176. van Kleef $M$, Weber WE, Kessels A, Dreyfuss P, Pauza K, Bogduk N. Re: Efficacy and validity of radiofrequency neurotomy for chroniclumbar zygapophysial joint pain (Spine 2000; 25:1270-1277). Spine 2001; 26:E163-E164.

177. Bogduk N. Lumbar radiofrequency neurotomy. Clin J Pain 2006; 22:409.

178. Jaeschke R, Guyatt G, Lijmer J. Diagnostic tests. In Guyatt G, Rennie D (eds). Users' Guides to the Medical Literature - A Manual for Evidence-Based Clinical Practice. AMA Press, Chicago, 2002, pp. 40.

179. Sackett DL, Haynes RB, Guyatt GH, Tugwell P. Clinical Epidemiology, A Basic Science for Clinical Medicine. 2nd ed. Little, Brown and Company, Boston, 1991:53-57.

180. Schwarzer AC, Derby R, Aprill CN, Fortin J, Kine G, Bogduk N. The value of the provocation response in lumbar zygapophysial joint injections. Clin J Pain 1994; 10:309-313. 